\title{
Further investigation of the response of the mammalian oviduct to catecholamines
}

\author{
K. E. Kendle and Y. K. Lam Shang Leen \\ School of Pharmacy, Robert Gordon's Institute, Schoolhill, Aberdeen AB9 1FR, U.K.
}

Following the histochemical demonstration of adrenergic innervation in the isthmus of the rabbit oviduct (Brundin, 1965) various studies have been undertaken to elucidate the functional significance of these nerves. Previous investigations have generally been confined to an evaluation of circular muscle activity (see Coutinho, Mattos \& da Silva, 1971; Heilman et al., 1972; Howe \& Black, 1973). Some recent work, however, has involved techniques for simultaneous recording of longitudinal and circular muscle activity in vitro (Ueda, Mattos \& Coutinho, 1973; Hunter \& Kendle, 1974). The latter study, on rabbits, indicated that the adrenoceptors of the circular muscle differed from those of the longitudinal muscle in being more sensitive to adrenaline than noradrenaline and in being specifically depressed when progesterone levels were high. The present work extends these observations by comparing the effects of adrenaline with those of noradrenaline on the oviducal circular muscle, longitudinal muscle and cardiovascular system in vivo. Preliminary studies of the cat were also undertaken to see whether these responses were found in another mammal.

Five mature New Zealand White does under oestrogen domination as indicated by absence of $\mathrm{CL}$ at autopsy and subsequently confirmed by uterine histology, were anaesthetized with $30 \mathrm{mg}$ sodium pentobarbitone/kg, supplemented when necessary with anaesthetic ether. The left carotid artery was exposed and a polyethylene cannula filled with heparinized saline (50 i.u. heparin $/ \mathrm{ml}$ $0.9 \% \mathrm{NaCl}, \mathrm{w} / \mathrm{v}$ ) was inserted to record blood pressure. A cannula connected to an automatic syringe was inserted into a jugular vein and the drugs were administered through the rubber connecting tube and washed into the circulation with $2.0 \mathrm{ml}$ saline.

The oviducts were exposed through a mid-ventral laparotomy incision and saline was infused through a cannula tied into the ovarian end of the left oviduct at a rate of $0.2 \mathrm{ml} / \mathrm{min}$ using a motorised syringe (C. F. Palmer (London) Ltd, High Wycombe). The resistance to flow was measured by a physiological pressure transducer (Model PT 400: George Washington Ltd, Sheerness) as an index of circular muscle activity. Two cotton ligatures approximately $2.5 \mathrm{~cm}$ apart were tied through the isthmus of the right oviduct, care being taken to avoid damage to the blood vessels. The ligatures were then secured to a force displacement transducer equipped with an adjustable inert bar which acted as an anchor point and isolated the isthmus from any uterine contractions. The anchor point was adjusted so that the tissue was initially under $5 \mathrm{~g}$ tension. Changes in tension recorded by the transducer were used as an index of longitudinal activity.

Estimates of the relative potency of adrenaline and noradrenaline were made on the circular, longitudinal and blood pressure indices by expressing the response to noradrenaline as a \% of the response to an equivalent dose of adrenaline. This determination was carried out at several dose levels within the range 4-16 $\mu \mathrm{M}$ of each drug in each animal, but subsequent examination of the results showed that the ratio obtained was independent of the dose level. Estimates from various submaximal doses in different animals were therefore pooled for analysis of significance of difference of response between tissues. Because the results were ratios of effects and therefore multiplicative factors, geometric means were taken and a logarithmic transformation was carried out before testing the significance of difference of the mean by Student's $t$ test.

The nature and distribution of adrenoceptors was also investigated by treatment with phentolamine as an $\alpha$-adrenoceptor-blocking drug, propranolol as a $\beta$-adrenoceptor blocker, practolol as a $\beta_{1}$ blocker and salbutamol as a specific $\beta_{2}$ stimulant. The doses used were those which were shown to produce changes in the cardiovascular responses, and were within the range 1-12 $\mathrm{mg}$ for the antagonists and 4-16 $\mu \mathrm{M}$ for salbutamol.

Preliminary investigations with the same techniques were also undertaken in two cats. 
Table 1. Responses of the rabbit oviduct and blood pressure to adrenaline and noradrenaline in vivo

\begin{tabular}{|c|c|c|c|}
\hline \multirow[b]{3}{*}{ Index } & \multicolumn{3}{|c|}{ Response to noradrenaline } \\
\hline & \multicolumn{3}{|c|}{ Response to same dose of adrenaline } \\
\hline & $\begin{array}{l}\text { No. of } \\
\text { estimates }\end{array}$ & Geometric mean & $\begin{array}{c}\text { Arithmetic mean of } \\
\operatorname{logs} \pm \text { S.E. }\end{array}$ \\
\hline Circular muscle & 18 & $28 \cdot 89^{*}$ & $1.4608 \pm 0.01925$ \\
\hline Longitudinal muscle & 7 & $170 \cdot 41^{*}$ & $2.2315 \pm 0.03088$ \\
\hline Blood pressure & 11 & $134 \cdot 07$ & $2 \cdot 1273 \pm 0.02460$ \\
\hline
\end{tabular}

* Significantly different, $P<0.001$.

The results given in Table 1 show that the nature and distribution of adrenoceptors present in the longitudinal muscle layer are similar to those in the vascular bed in so far as noradrenaline was a more potent spasmogen than adrenaline in both tissues and the mean ratios of relative activity of the amines were not significantly different $(P>0.01)$. The receptors of the circular muscle layer appeared to be different, however, since the relative activities of adrenaline and noradrenaline were significantly different $(P<0.001)$ from those of the longitudinal muscle layer.

Table 2. Effects of sympathomimetics and adrenoceptor-blocking drugs on oviduct and blood pressure responses in anaesthetized rabbits

\begin{tabular}{|c|c|c|c|}
\hline & Circular muscle & Longitudinal muscle & Blood pressure \\
\hline $\begin{array}{l}\text { Adrenaline } \\
\text { Adrenaline + phentolamine } \\
\text { Adrenaline + propranolol } \\
\text { Adrenaline + practolol } \\
\text { Salbutamol }\end{array}$ & $\begin{array}{l}\text { Contraction } \\
\text { Contraction blocked } \\
\text { Potentiated contraction } \\
\text { Potentiated contraction } \\
\text { No effect }\end{array}$ & $\begin{array}{l}\text { Contraction } \\
\text { Contraction blocked } \\
\text { Potentiated contraction } \\
\text { Not potentiated } \\
\text { Inhibition }\end{array}$ & $\begin{array}{l}\text { Rise } \\
\text { Rise blocked } \\
\text { Potentiated rise } \\
\text { Depressed rise } \\
\text { Fall* }\end{array}$ \\
\hline
\end{tabular}

* Slight in some animals.

The results given in Table 2 show that the motor effects of adrenaline on all three tissues ar blocked by phentolamine and potentiated by propranolol. Practolol however was shown to potentiate only the circular muscle contraction, while causing inhibition of the blood pressure effects of adrenaline. Salbutamol was without effect on the circular muscle but caused inhibition of longitudinal muscle contraction. In the cats, adrenaline and noradrenaline caused predominantly inhibitory responses in circular and longitudinal muscle.

The difference in the relative potencies of adrenaline and noradrenaline on the longitudinal and circular muscle layers of the oviduct confirms the findings of Hunter \& Kendle (1974) and extends these observations by showing quantitative differences in vivo. The present results with a specific $\beta_{1}$ antagonist and $\beta_{2}$ stimulant indicate that the inhibitory receptor in the circular muscle layer is of the $\beta_{1}$ type, while that in the longitudinal muscle is of the $\beta_{2}$ type. The results also confirm and extend the findings of other workers that the longitudinal and circular muscle layers of the rabbit oviduct contain excitatory $\alpha$-adrenoceptors and inhibitory $\beta$-adrenoceptors (Longley, Black \& Currie, 1968; Ueda et al., 1973; Howe \& Black, 1973). These differences in $\beta$-receptor type may partly explain the different relative potencies of adrenaline and noradrenaline on the circular and longitudinal muscle. Since noradrenaline stimulates $\beta_{1}$-receptors, the circular muscle response to adrenaline and noradrenaline would be the algebraic sum of motor and inhibitor responses. In the longitudinal muscle layer, however, the adrenaline response would also be a mixed motor-inhibitor response, while that of noradrenaline would be a pure motor response as noradrenaline is ineffective on $\beta_{2}$-receptors. 
The finding that the adrenoceptors of the cat oviduct are different from those in the rabbit shows, however, that the demonstration of atypical receptor systems in the rabbit oviduct is not generally applicable to the mammalian oviduct. Results obtained in the rabbit therefore will not necessarily provide a basis for the control of human fertility, unless it is first shown that the human and rabbit oviducts have similar receptor systems.

The authors are indebted to Mr A. W. Wilson for statistical advice and help.

\section{References}

BRUNDIN, J. (1965) Distribution and function of adrenergic nerves in the rabbit Fallopian tube. Acta physiol. scand. 66, Suppl. 259.

Coutinho, E.M., Mattos, C.E.R. \& DA Silva, A.R. (1971) The effect of ovarian hormones on adrenergic stimulation of the rabbit Fallopian tube. Fert. Steril. 22, 311-317.

Heilman, R.D., ECKhard, W., Bauer, B.S., Herhn, D.W. \& DA VANZO, J.P. (1972) A comparison of cardiovascular and oviduct beta adrenergic receptors. Fert. Steril. 23, 221-229.

Howe, G.R. \& Black, D.L. (1973) Autonomic nervous system and oviduct function in the rabbit. I. Hormones and contraction. J. Reprod. Fert. 33, 425-430.
HuNTER, D.S. \& KENDLE, K.E. (1974) The influence of hormonal state on the response of the isolated rabbit oviduct to catecholamines. J. Reprod. Fert. 41, 245-247.

Longley, W.J., Black, D.L. \& Currie, C.M. (1968) Oviduct circular muscle response to drugs related to the autonomic nervous system. J. Reprod. Fert. 17, 95-100.

Ueda, M., Mattos, C.E. \& Coutinho, E.M. (1973) The influence of adrenergic activation and blockade on the mobility of the circular and longitudinal muscle layers of the rabbit oviduct in vitro. Fert. Steril. 24, 440-447.

Received 1 May 1975 